\title{
Assessment of heavy metal pollution of effluents from three food industries within Onitsha in Anambra State, Nigeria
}

\author{
Nwosu Udoka Lovelyn", Ajiwe Vincent Ishmael Egbulezu², Okoye Patrick-Anthony Chudi ${ }^{2}$ \\ ${ }^{1}$ Department of Food Technology, Federal Polytechnic, Oko, Nigeria \\ ${ }^{2}$ Department of Pure and Industrial Chemistry, Nnamdi Azikiwe University, Awka, Nigeria
}

Email address:

Udolove4sure@gmail.com (U. L. Nwosu), vaj_04@yahoo.com (V. I. E. Ajiwe), pacnau05@yahoo.com (Patrick-Anthony C. O.)

\section{To cite this article:}

Nwosu Udoka Lovelyn, Ajiwe Vincent Ishmael Egbulezu, Okoye Patrick-Anthony Chudi. Assessment of Heavy Metal Pollution of Effluents from Three Food Industries within Onitsha in Anambra State, Nigeria. International Journal of Environmental Monitoring and Analysis. Vol. 2, No. 5, 2014, pp. 259-265. doi: 10.11648/j.ijema.20140205.15

\begin{abstract}
This work investigated the heavy metal pollution of effluents from three food industries within Onitsha in Anambra State, Nigeria. The wastewater samples were analyzed for heavy metals using Atomic Absorption Spectrophotometer. Results showed that the mean levels of all the heavy metals were above the limit allowed by the Nigeria Federal Ministry of Environment in industrial effluent. Concentrations of heavy metals obtained were higher in the dry season than in the rainy season. $\mathrm{Hg}$ in the effluents were in the order of Life $<$ Golden $<$ Savanna (rainy season) against the values obtained in the dry season of Life $<$ Savanna $<$ Golden. Two sample paired t-test showed that the mean levels of $\mathrm{Pb}, \mathrm{Cr}, \mathrm{As}, \mathrm{Cd}$ and $\mathrm{Zn}$ were not significant $(p>0.05)$ between rainy and dry season. Analysis of variance showed that apart from arsenic, the concentrations of $\mathrm{Hg}, \mathrm{Fe}, \mathrm{Pb}, \mathrm{Cr}, \mathrm{Cd}$ were not significant ( $\mathrm{p}>0.05$ ) when the effluents were compared to each other. Nevertheless, the pollution index of the heavy metals showed significant pollution by these toxicants.
\end{abstract}

Keywords: Food Industries, Heavy Metals, Effluents, Pollution, Assessment

\section{Introduction}

The untreated industrial and municipal wastes have created multiple environmental hazards for mankind. Effluent discharges from the industries are world wide sources of potential pollution (Ajao, 1985). In Nigeria, the major sources of heavy metal pollution are industrial effluents discharged from various processing industries. This increases the influx of metals, which can be transported by wind, and water, thus become available to plants and animals. These heavy metals attain a higher concentrations and accumulate in dangerous quantity in different plant's part and finally pose serious health hazard to human beings and the animals through biomagnifications (Ray, 1990).

Among the environmental pollutants, metals are of particular concern, due to their potential toxic effect and ability to bioaccumulate in aquatic ecosystem (Censi et al., 2006). Studies on heavy metals in rivers, lakes, fish and sediments (Ozmen et al,, 2005; Fernandes et al., 2008; Pote et al., 2008; Praveena et al., 2008) have been a major environmental focus especially during the last decades. Heavy metals including both essential and non-essential elements have a significance in ecotoxicology, since they are highly persistent and all have the potential to be toxic to living organisms (Storelli et al, 2005). Heavy metals such as copper, iron, chromium and Nickel are essential metals since they play an important role in biological systems, whereas cadmium and lead are non-essential metals, as they are toxic, even in trace amounts (Canli and Atli, 2003).

Heavy metal pollution is a problem associated with the areas of intensive industrial activities (Kolodynska, 2010), from where untreated effluents are introduced into the environment. The effluents usually contain toxic metals like cadmium, mercury, silver, lead and others like zinc, copper and Nickel which are toxic at elevated concentrations (Sunda and Huntsman, 1998; Chojnacka et al., 2004), where they percolate into the ground water, cultivated crops and pose a significant threat to human health and ecological systems (Najafia et al., 2011).

Industrialization, no doubt, develops the world and makes life better through creation of wealth and employment 
opportunities. Ironically, human lives are being hunted by the huge volume of wastes emanating from these industries, especially when they are discharged into the environment without proper treatment. Local impacts are particularly obvious because these wastes are generally generated throughout the year giving no room for the environment to recover. Many of these food industries discharge their wastewaters directly into rivers, streams or into open gutters causing serious environmental problems. The basic issue according to Chukwu, (2008) is how industrial development can actually take place without necessarily destroying the environment. This is the import of evaluating the environmental impact of effluents from industries.

Ideally, citing of industries should strive a balance between socio-economic and environmental considerations, but here in Nigeria, this is not the case as citing of industries is determined by various criteria, some of which are environmentally unacceptable, thereby posing serious threat to public health. It was against this background that this work was initiated, to assess the heavy metal pollution of effluents from three food processing industries in Onitsha, Anambra State, Nigeria.

\section{Materials and Method}

\subsection{Sample Collection}

Wastewater samples are collected from three different food industries within Onitsha area of Anambra State. Effluents were collected at one month interval from JuneSeptember 2010 (rainy season) and October 2010 - January, 2011 (dry season). Four months rainy season and four months dry season for easy comparison. A total of eight sampling trips were made in each of the food industries. The wastewater samples were collected at three different spots along the effluent pathways from the point of discharge $\left(\mathrm{P}_{1}\right)$ to 60 meters away from the point of discharge $\left(\mathrm{P}_{3}\right)$.

The first sample was collected from the point of discharge $\left(\mathrm{P}_{1}\right)$ of the effluent, another, at 30 meters away from the point of discharge $\left(\mathrm{P}_{2}\right)$, finally, 60 meters away from the point of discharge $\left(\mathrm{P}_{3}\right)$, making a total of three sampling spots per food industry per month. Effluent samples were also collected along the Savanna effluent pathway at the point of discharge only, $\left(\mathrm{P}_{1}\right)$ before Life Breweries effluent and Savanna effluent coalesced at a point.

Samples were collected using a 2-litre plastic container with a screw cap. The container was initially washed with detergent, rinsed with distilled water and at the point of collection, it was rinsed three times with the sample before collection.

\subsection{Determination of Heavy Metal}

Each wastewater sample was wet digested with a 2:1 mixture of nitric acid and perchloric acid. The digested sample was evaporated to almost dryness and then made up to $100 \mathrm{ml}$ with distilled water. $50 \mathrm{ml}$ of standard solution of different metals were prepared from their respective salts. From each stock - solution was prepared 1,2,3,4 and 5 ppm of each metal for calibration study. Concentration of the working ranges were obtained by diluting an appropriate volume of the stock solution. The concentrations of the metals were determined in an air acetylene flame using Atomic Absorption Spectrophotometer (AAS) UNICAN Sp 1900. The equipment was previously standardized and corrected for background metal impurities using a blank determination.

\subsection{Analysis of Data}

Means of triplicate readings obtained in this work were subjected to statistical analysis using statistical package for social science (SPSS version 20 computer software) to see if there were significant difference in the mean levels of the heavy metals between the two seasons and to see if the mean concentrations of the heavy metals varied among the three different effluents monitored. Significance was accepted at the $\mathrm{P}<0.05$ level.

\section{Results}

The result of the mean concentrations of the heavy metals in the effluent samples from the three food processing industries within Onitsha area of Anambra State in both rainy and dry seasons compared with the Federal Ministry of Environment effluent limitation guidelines are presented in Table 1. Again, figures 1.1-1.10 represent the mean levels of the heavy metals by season and location.

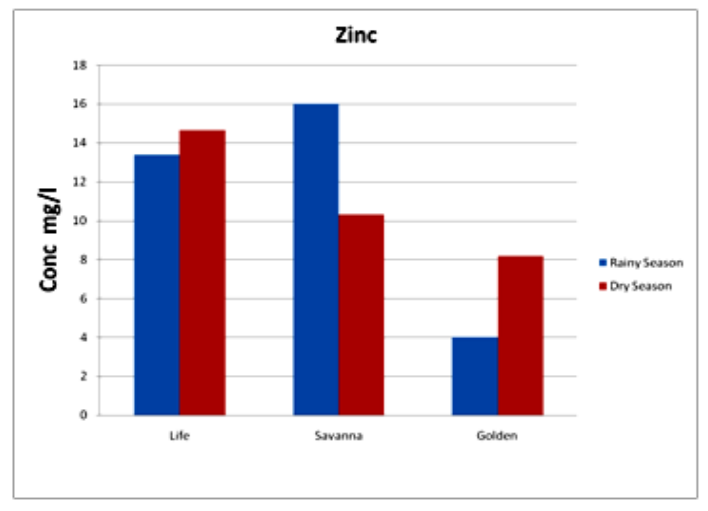

Fig. 1.1. Zinc level by season and locations

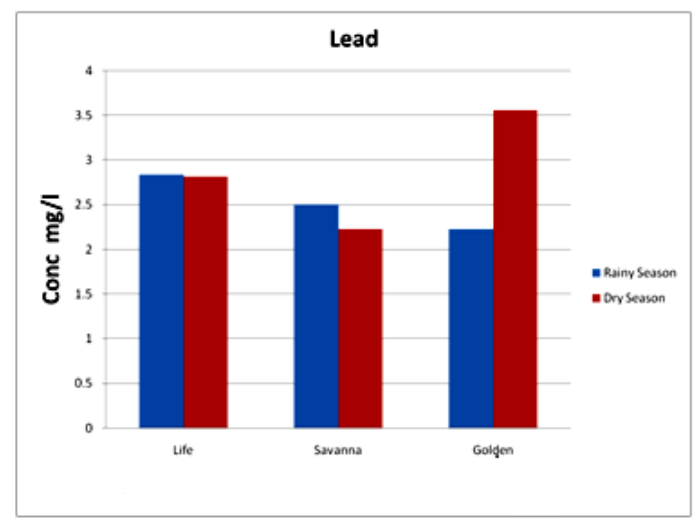

Fig. 1.2. Lead level by season and locations 


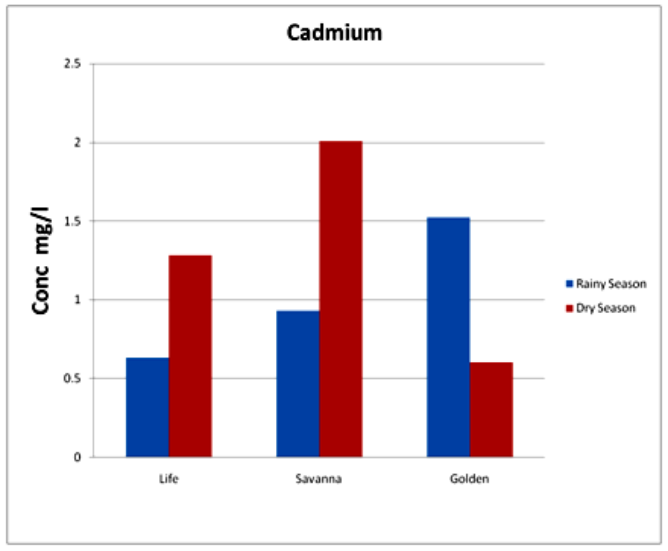

Fig. 1.3. Cadmium level by season and locations

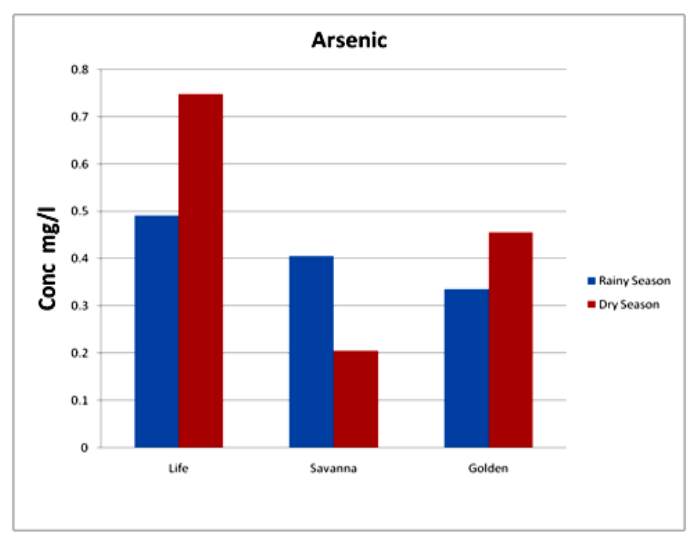

Fig. 1.4. Arsenic level by season and locations

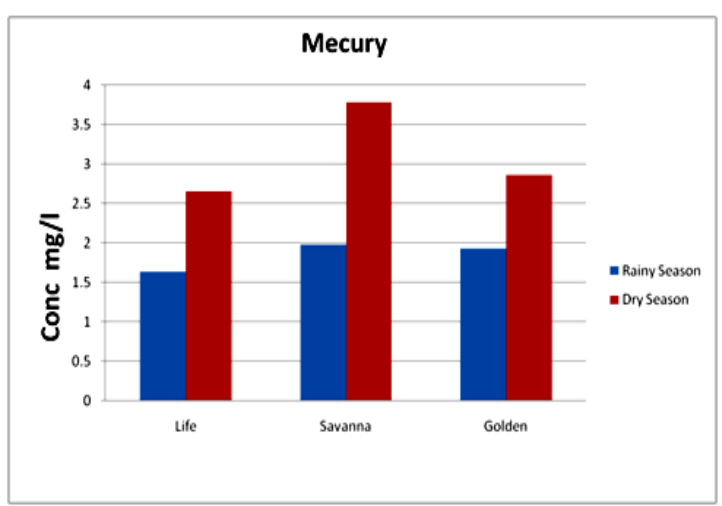

Fig. 1.5. Mercury level by season and locations

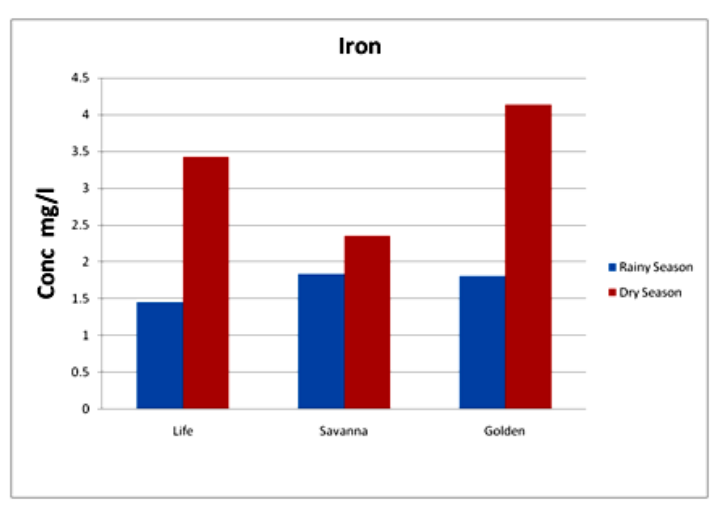

Fig. 1.6. Iron level by season and locations

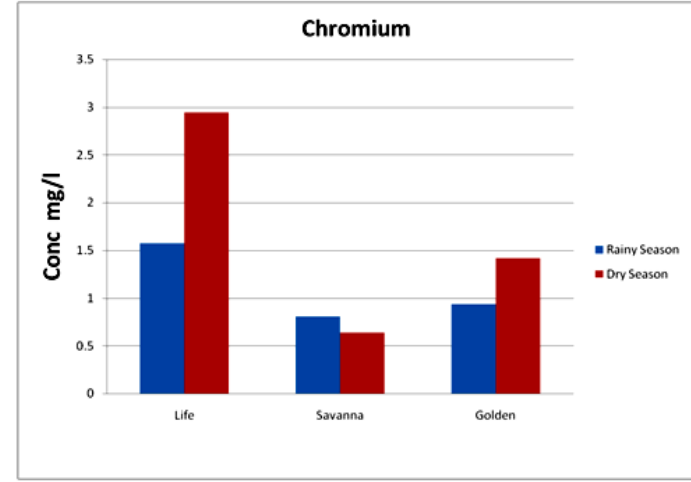

Fig. 1.7. Chromium level by season and locations

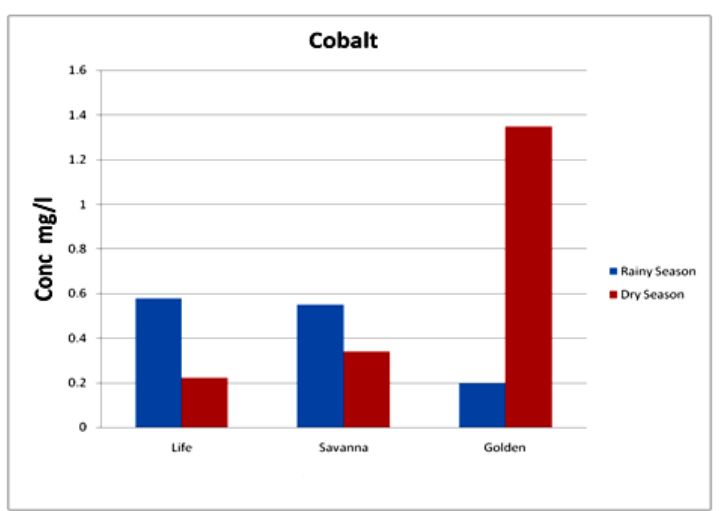

Fig. 1.8. Cobalt level by season and locations

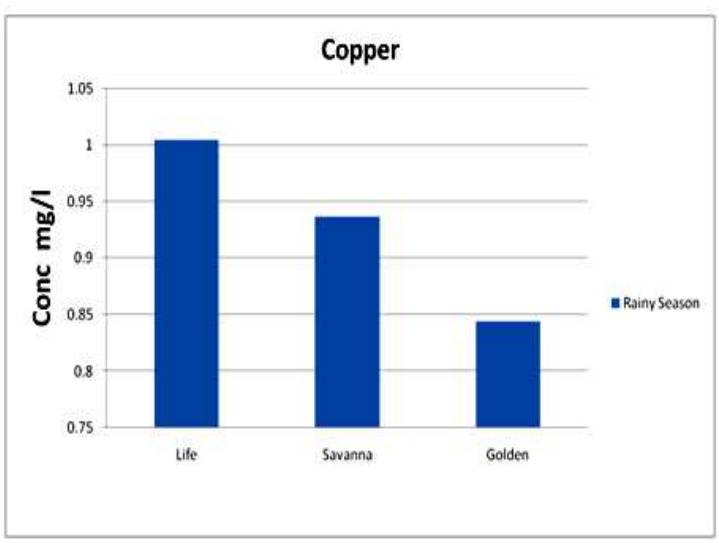

Fig. 1.9. Copper level by season and locations

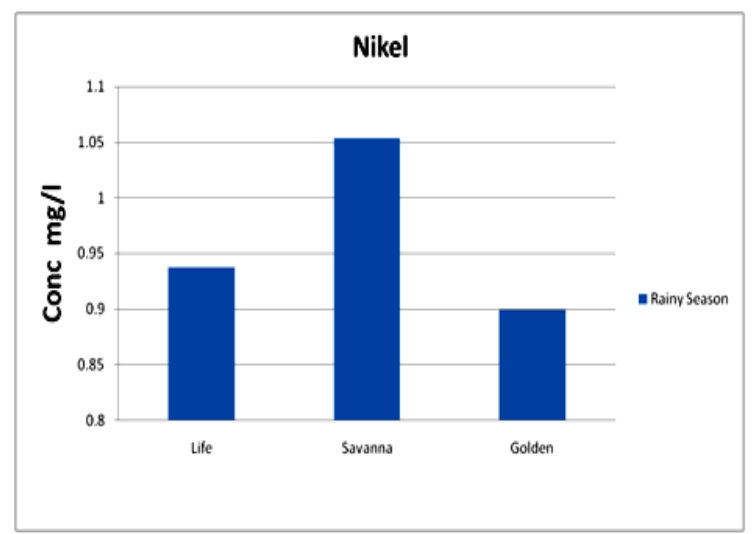

Fig. 1.10. Nikel level by season and locations 


\section{Discussion}

Table 1 showed that copper and Nickel were not detected in the dry season in the three effluents monitored, but were detected in the rainy season. This could be attributed to the fact that these heavy metals were concentrated in the air around the food industries as sprays or droplets during the dry season, and with the arrival of rain, they were washed down through precipitation and mixed with the effluents, leading to increase in the concentrations of these heavy metals in the rainy season. This was in line with the findings of Singare et al., (2011) who reported that Nickel is released into the air by power plants and trash incinerators and will settle to the ground or fall down after it reacts with precipitations.

Values obtained for these two heavy metals in the rainy season were within the limit set by FMENV, (1991) except in Life Breweries effluent (copper) and Savanna effluent (Nickel). Arsenic appeared in the concentrations that were within the effluent limit while $\mathrm{Zn}, \mathrm{Pb}, \mathrm{Hg}$ and Fe occurred at concentrations higher than the effluent limitation guidelines recommended by the Federal Ministry of Environment in all the effluent samples monitored in both seasons.

Mean concentrations of $\mathrm{Hg}, \mathrm{Fe}, \mathrm{Cr}$, and $\mathrm{Zn}$ (except Savanna effluent) were lower in the rainy season than in the dry season in all the effluents monitored. This could be as a result of dilution through precipitation or leaching away of the metals by flood into the receiving water bodies.

Figure 1.1 showed that $\mathrm{Zn}$ recorded values that were high in the three effluent samples monitored in both seasons when compared to the values recommended by the Federal Ministry of Environment (FMENV), (1991) in industrial effluent (Table 1). Highest value of Zinc was obtained in Savanna effluent (rainy season) while Golden effluent had the least mean concentration of $\mathrm{Zn}$ in both seasons. Among all the heavy metals, $\mathrm{Zn}$ is the least toxic and essential element in human diet as it is required to maintain the functioning of the immune systems. Zinc deficiency, according to Ladipo and Doherty, (2011), in the diet may be highly detrimental to human health than too much $\mathrm{Zn}$ in the diet. Again, Kola et al., (2009) reported that $\mathrm{Zn}$ is one of the essential elements for human health and metabolism. However, statistical analysis showed that there was no significant different $(\mathrm{P}<0.05)$ in the mean levels of $\mathrm{Zn}$ between the two seasons but was significant among the three effluents especially between Life and Golden (P-value 0.03).

Apart from Golden effluent, the concentrations of $\mathrm{Pb}$ (Fig 1.2) were higher in the rainy season than that of dry season (Table 1). Highest concentration of $\mathrm{Pb}$ was obtained in Golden effluent (Dry season) which also had the least value in the rainy season. The trend in the concentration of $\mathrm{Pb}$ in the effluents were Golden> Life> Savanna (Dry season) and Life>Savanna> Golden (Rainy season). Though the mean levels of $\mathrm{Pb}$ in the effluents were higher in the rainy season (Apart from Golden effluent), statistical analysis showed that there was no significant difference $(p>0.05)$ in the levels of this metal between rainy and dry season (f-value 2.578; pvalue 0.111 ). Lead values obtained in Golden effluent (Dry season) was higher than $\mathrm{Pb}$ values $(0.034 \mathrm{mg} / \mathrm{l})$ reported by Oguzie, (1999) for Ikpoba river. Vasudevan and Streakumari, (2000) reported that $\mathrm{Pb}$ inhibits red blood cell-enzyme systems, and can displace calcium in bone to form softer denser sports which according to Underwood, (2002) activates cysteine containing enzymes, allowing more internal toxicity from free radical chemicals and other heavy metals.

Cadmium levels were highest in effluent sample from Savanna (dry season), followed by Golden effluent (rainy season).The least mean value of $\mathrm{Cd}$ was obtained in Golden effluent (Dry season), which was within the allowable limited (FMENV, 1991). (Table 1). This was in line with the findings of Oguzie and Okhagbuzo, (2010), who reported low Cd levels in effluents discharges of Ikpoba river. This not withstanding, statistical analysis showed that there was no significant difference $(p>0.05)$ in the levels of this heavy metal between rainy and dry season. Cadmium adversely affects several important enzymes. It can cause painful osteomalacia (bone disease), destruction of red blood cell and kidney damage (Odo and Kolawole, 2011).

The total mean levels of arsenic were observed to be higher in the dry season than rainy season in effluent samples from Life and Golden, though it appeared in concentrations that were within the limit recommended by the Federal Ministry of Environment (FMENV, (1991) in industrial effluents to be discharged into the environment (Table 1). Two sample paired t-test showed that there was no significant difference ( $p>0.05)$ in the total mean levels of this heavy metal in the effluent samples between rainy and dry season. Investigation showed that a severe poisoning could arise from ingestion of a little as $100 \mathrm{mg}$ of arsenic as a result of pollution from weed killers and pesticides containing arsenical compounds.

The concentrations of $\mathrm{Hg}$ (Fig. 1.5) were also higher in the dry season than in rainy season in all the effluent samples monitored. Concentrations of $\mathrm{Hg}$ in the dry season decreased in the order Golden $>$ Savanna $>$ Life but in the rainy season, the trend was Savanna $>$ Golden $>$ Life. Hence, Life effluent had the least value of $\mathrm{Hg}$ in both seasons. Values of $\mathrm{Hg}$ obtained in this work were higher than maximum allowable limit of $0.05 \mathrm{mg} / \mathrm{l}$ prescribed by the Federal Ministry of Environment (FMENV), (1991) for industrial effluent limitation. This was confirmed by the statistical analysis which showed that $\mathrm{Hg}$ levels were highly significant $(\mathrm{p}<0.05)$ between rainy and dry season. The danger of the presence of $\mathrm{Hg}$ in seafood were demonstrated by the appearance in the 1950s and 60s of a crippling neurological disorder among the inhabitants of a town in Southern Japan where Peter and Michael, (2005) reported that victims were poisoned by eating fish and shell fish that had concentrated $\mathrm{Hg}$ discharged at sea by a chemical plant.

Figure 1.6 showed that the levels of Fe in the effluent samples monitored were higher in the dry season than values obtained in the rainy season. Highest value was obtained in Golden effluent $(4.139 \pm 0.706 \mathrm{mg} / \mathrm{l})$, while Savanna effluent was the least $(2.350 \pm 1.223 \mathrm{mg} / \mathrm{l})$ in the same season (Table 1$)$. Values obtained for this metal in the three effluents were above 
the maximum permissible limit in industrial effluent. Low concentration of iron in the rainy season could be as a result of dilution through precipitation. Two sample paired t-test confirmed that there was significant difference $(p<0.05)$ in the levels of this heavy metal between the two seasons though there were no significant difference ( $>>0.05)$ among the different effluent sample as regards the concentration of iron.

Chromium levels in the three effluents were higher in the dry season than values obtained in the rainy season, except Savanna effluent where reverse was the case. Highest chromium level was obtained in Life effluent (Dry season) and the least level of this metal was obtained in Savana effluent in the same season. With the exception of Life effluent (both seasons) and Golden effluent (dry season), other effluents gave chromium values that were within the effluent limitation guideline.

Chromium levels obtained in this work were higher than the value $(0.079 \mathrm{mg} / \mathrm{l})$ reported by Oguzie and Okhagbuzo, (2010) for effluent discharges downstream of Ikpoba river in Benin city, but no significant difference $(p>0.05)$ was observed in the concentration of this heavy metal between rainy and dry season.

Apart from Golden effluent, the total mean concentration of cobalt (Fig. 1. 8) was higher in the rainy season than in the dry season. Golden effluent recorded the highest mean level of cobalt (dry season). The trend of cobalt in the effluents (dry season) was Golden $>$ Savanna $>$ Life while that of rainy season was Life $>$ Savanna $>$ Golden. However, there was no significant difference $(p>0.05)$ in the concentration of this metal between rainy and dry seasons (f-value 2.782; p-value 0.109).

Copper and Nickel were not detected in the three effluent samples (dry season), but were detected in the rainy season. Highest concentration of copper was obtained in life effluent, while Golden effluent recorded the least value of both copper and nickel. Values obtained for these two heavy metals (apart from copper in Life effluent and nickel in Savanna effluent) were within the limit recommended by the Federal Ministry of Environment (FMENV), (1991) in industrial effluents.

Toxic metals may be absorbed by crops through several processes and finally enter the food chain at high concentrations capable of causing a serious health risk to consumers. Their toxicity, according to Charles et al., (2011) can damage or reduce central nervous function, lower energy levels and damage to blood composition, lungs, kidneys, liver and other vital organs.

Table 2 showed the pollution index of the heavy metals in the three effluent samples investigated. Pollution index is expressed as a function of the concentration of individual heavy metal against the baseline standard. Generally, pollution index of more than one $(\mathrm{Pi}>1.000)$ showed that the average heavy metal concentrations were above the permissible limit, while values less than one $(\mathrm{Pi}<1.000)$ showed no pollution.

However, pollution index values obtained in this work showed that the three industries monitored were polluted by these heavy metals since the index values were more than one $(\mathrm{Pi}>1.000)$. Pollution in these food industries ranked in decreasing order of Savanna> Life $>$ Golden showing that Savanna effluent was the most polluted in terms of toxic heavy metals while Golden effluents was the least polluted (Table 2). Thus, these effluents need to be properly treated before they are discharged into the environment to avert serious health challenges they might pose to human beings.

\section{Conclusion and Recommendations}

Table 1. Mean concentration values ( $\mathrm{mg} / \mathrm{l})$ of the heavy metals in the effluents

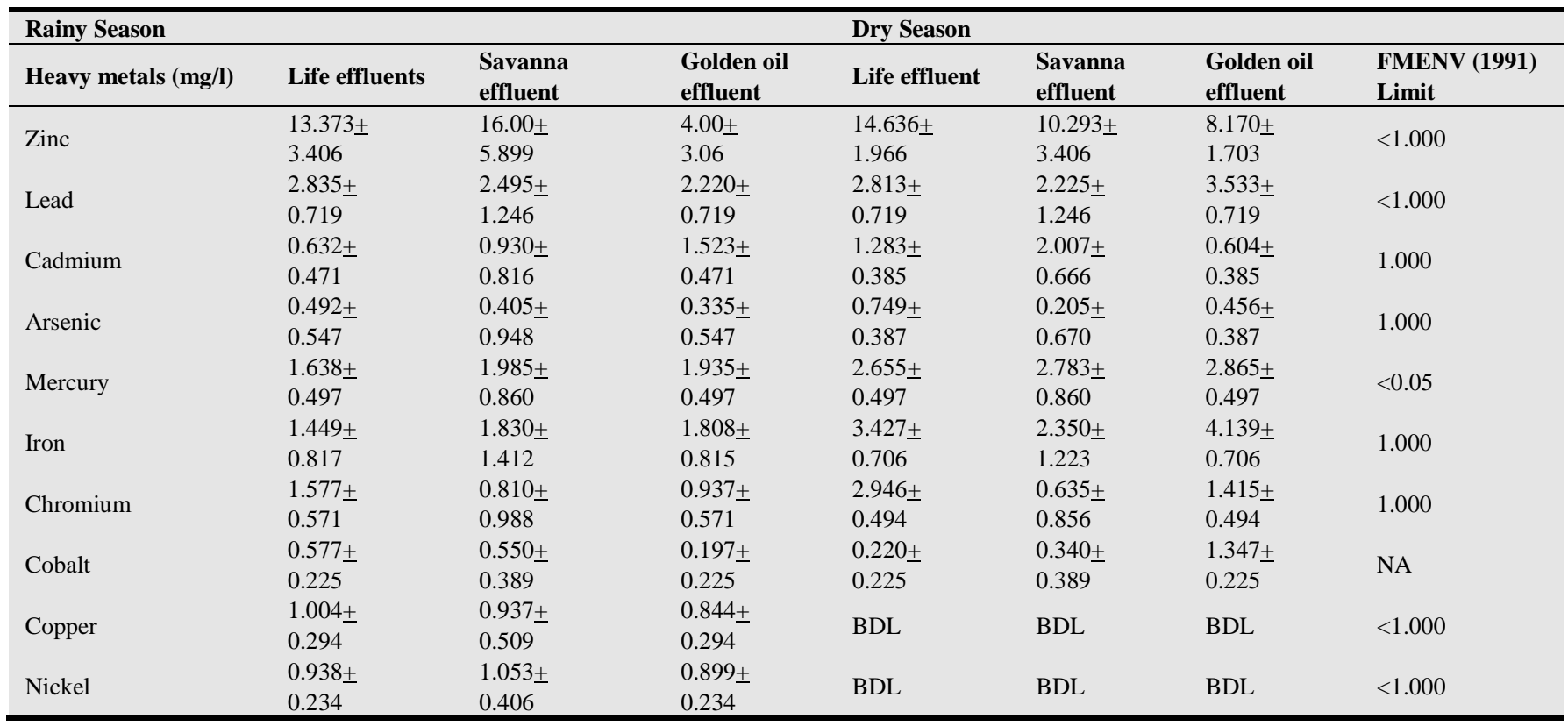

Values are means of triplicate readings \pm SE

Significant difference at $\mathrm{P}<0.05$

BDL - Below Detection Limit 
This study showed that the concentrations of $\mathrm{Zn}, \mathrm{Pb}, \mathrm{Cd}$, $\mathrm{Hg}, \mathrm{Fe}$ and $\mathrm{Cr}$ were high in the effluent samples monitored. Their levels were higher than the allowable limitation guidelines documented by the Federal Ministry of Environment in industrial effluents. The mean concentrations of these heavy metals were higher in the dry season than in the rainy season (except copper and Nickel) in the three effluent samples monitored. However, result of the two sample paired t-test showed that the mean concentration of all the heavy metals (except $\mathrm{Hg}$ and $\mathrm{Fe}$ ) were not significantly different $(\mathrm{P}>0.05)$ between rainy and dry season. Pollution index profile of the heavy metals showed high degree of pollution especially in Savanna effluent with index of 13.3378 .

Pollution by heavy metals in the food processing industries studied was in the order: Savanna>Life>Golden. This implied that continued discharge of these effluents without proper treatment could lead to further accumulation of these toxicants in aquatic organisms, crops and human beings leading to different kinds of health challenges.

It is therefore recommended that these industries should be made to install a treatment plant in their various factories. Incentives should be given to industries that not only install a treatment plant, but also treat their wastewater properly. This might encourage other industries to comply to the laid down rules.

Table 2. Pollution Index of the heavy meals

\begin{tabular}{lllllllll}
\hline & $\mathbf{H g}$ & $\mathbf{F e}$ & $\mathbf{C r}$ & $\mathbf{P b}$ & $\mathbf{C d}$ & $\mathbf{Z n}$ & As & Pi \\
\hline Life & 2.6650 & 3.4267 & 2.9458 & 2.8125 & 1.2833 & 14.6356 & 0.7491 & 11.279 \\
Savana & 3.7825 & 2.3500 & 0.6350 & 2.2250 & 2.0067 & 10.2933 & 0.2050 & 13.3378 \\
Golden & 2.8650 & 4.1392 & 1.4150 & 3.4533 & 0.6044 & 8.1700 & 0.4559 & 10.8054 \\
\hline
\end{tabular}

\section{References}

[1] Ajao, E.A., Acute Toxicity Test of a Textile Mill Waste-Water Effluent and a Detergent Wash with a Hermit Crab Clibinarinus anfrucanus (Aurvillius). NIOMR Tech Paper 21. p.11. 1985.

[2] Begum, A., Amin, M.d.N., Kaneco, S., Ohta, K., Selected elemental composition of the muscle tissue of three species of fish, Tilapia nilotica, Cirrhina mrigala and clarius batrachus, from the fresh water Dhamondi Lake in Bangladeshi. Food Chemistry, 93, 439-443. 2005.

[3] Canli, M., Atli, G., The relationships between heavy metal (Cd, $\mathrm{Cr}, \mathrm{Cu}, \mathrm{Fe}, \mathrm{Pb}, \mathrm{Zn}$ ) levels and the size of six Mediterranean fish species. Environs Ollut. 121, 129-136. 2003.

[4] Censi, P., Spoto, S.E., Saiano, F, Sprovrerri, N., Massola, S., Nardone, G., D. Geronimo, S.I., Punturo, R., Ottonello, D., Heavy metals in coastal water systems. A case study from the Northwestern Gulf of Thailand. Chemosphere, 64, 1167-1176. 2006.

[5] Charles, K.W., Mwegoha, J.S., Riziki, S.S., Heavy metal concentrations in vegetables grown in the vicinity of the closed dump site. International Journal of Environmental Series, 2 (2), 889-895. 2011.

[6] Chinnaka, K., Chojuaciki, A., Gorecka, H., Trace element removal by spirulina $s p$. from copper smelter and refinery effluents. Hydrometallurgy, 73, 149-153. 2004.

[7] Chukwu, D., Impact of food processing effluents on the receiving streams. Environmental Research Journal, 2 (5), 222-225. 2008.

[8] FEPA., Guidelines and standards for Environmental Pollution control in Nigeria, Federal Environmental Agency (FEPA), Lagos, Nigeria p. 238. 1991.

[9] Fernades, C., Fontainhas-Fernandes, A., Cabral, D., Salgado, M.A., Heavy metals in water, sediment, and tissues of liza saliens from Es moriz-paramos lagoon, Portugal. Envron. Monit. Assess, 136, 267-275. 2008.

[10] Kolo, B., Dibal, J.M., Ndakaw, I.I., Elemental Analysis of Tap and Borehole waters in Maiduguri, Semi Arid Region, Nigeria. European Journal of Applied Sciences, 1(2), 26-29. 2009.

[11] Kolodynska, D., The effects of the Novel complexity agent in removal of heavy metal ions from waters and wastewaters. chem. Engine. J., 165, 535-845. 2010.

[12] Ladipo, M.K., and Dohorty, V.F., Heavy metal level in vegetables from selected markets in Lagos, Nigeria. African Journal of Food Science and Technology, 2(1), 018-021. 2011.

[13] Najafia, M., Rostamian, R., Rafati, A.A., Chemically modified silica gel with throl group as an absorbent for retention of some toxic soft metal ions from water and industrial effluent. Chem. Eng. J., 168, 426-432. 2011.

[14] Odo, R. and Kolawole, S., Assessment of trace heavy metal contamination of some selected vegetables irrigated with water from Benue River within Makurdi metropolis, Benue State, Nigeria. Advances in Applied Science Research, 2 (5), 590-601. 2011.

[15] Oguzie, F.A. and Okhagbuzo, G., Concentrations of heavy metals in effluent discharges down stream Ikpoba River in Benin City, Nigeria. African J. of Biotechnology, 9(3), 319325. 2010.

[16] Oguzie, F.A., Contribution of Industrial Effluents to the Heavy Metal loads of the Lower Ikpoba River in Benin City, Nigeria. Africa J. Appl.zool., 2, 60-63. 1999.

[17] Ozmen, H., Kulahci, F., Cukorovali, A., Dogru, M.,. Concentration of heavy metal and radio-activity in surface water and sediment of Hazar lake (Elazig, Turkey), Chemosphere, 55; 401-408. 2004.

[18] Ozturk, M., Ozozen, G., Minareci., O., Minareci, E., Determination of heavy metals in fishes, water and sediment from the Demirkopru Dam Lake (Turkey). Journal of Applied Biological Sciences, 2 (3), 99-104. 2008. 
[19] Peter, C.H. and Micheal, E.H., Marine Biology, $5^{\text {th }}$ ed. McGraw Hill Publishing Company. New York. Pp. 400-401. 2005.

[20] Pote, J., Haller, L., Loizeau, J.L., Bravo, A.G., Sastre, V., W. Idi, W., Effect of a Sewage treatment plant outlet pipe extension on the distribution of contaminants in the sediments of the Bay of Vidy, Lake Geneva, Switzerland Bioresource Technol., 99, 7122-7131. 2008.

[21] Praveena, S.M., Radojevic, M., Abdullah, M.H., Aris, A., Application of sediment quality guidelines in the assessment of mangrove surface sediment in Mengkabong lagoon, Sabah, Malaysia. Iran. J. Environ. Health, Sci. Eng., 5 (1), 35-42. 2008.

[22] Ray M., Accumulation of heavy metals in plants grown in Industrial areas. Indian Biologists, XXII (2), 33-38. 1990.
[23] Storelli, M.M., Storelli, A., D'ddabbo, R., Marano, C., Bruno, R., Marcotrigiano, G.O., Trace elements in loggerhead turtles (caretta caretta) from the eastern Mediterranean sea: overview and evaluation. Environ. Pollut, 135, 163-170. 2005.

[24] Sunda, N.G. and Huntsmamn, S.A., Process regulating cellular metal accumulation and physiological effects, phytoplankton as model systems. Science of the total Environ, 6, 165-181. 1998.

[25] Underwood, L.S., Long Term Effects of childhood exposure to lead at low dose. An eleven years follow-up Report. New England J. of Medicine, 322, 83-88. 2002.

[26] Vasuderon, D.M. and Streekumeri, S., Biochemical Aspects of Environmental Pollution. Textbook of Biochemistry for Medical students, $2^{\text {nd }}$ ed. Jay Pee Brothers Medical Publishers Ltd. New Delhi, India pp. 467-485. 2000. 